\title{
ALTERNATIVE STRATEGY TO EMPOWER AND DEVELOP BATIK BUSINESS AS COMMUNITY WELFARE SUPPORT IN PURWOREJO - INDONESIA
}

\begin{abstract}
This research aimed to find facts on weaknesses and constraints that occurred in the field, and tried to prepare an alternative strategy model for supervising and empowering batik business to boost Purworejo's community economic welfare. The research was held in a number of sub-regions which it was known as batik culture area in the past time. This research applied qualitative methods to obtain in-depth illustration on real situation and condition in the field. The result concluded that to develop and to empower Purworejo's Batik, it was needed an alternative strategy, which included the comprehensive planning and supervising on batik industries in Purworejo. Batik craftsmen and business players were necessary to be empowered on business location, physical equipment, supporting goods, raw materials, products design, energy, manpower and time. Beside from the Government side, it was necessary such a strong political willingness on general policy and specially that aim for empowering and increase batik industry to become master in its own country.
\end{abstract}

Keywords: Batik Business, Batik Craftman, Purworejo, Batik.

\section{INTRODUCTION}

Nowadays, batik has been officially recognized by Indonesia as the original intangible heritage of a country. Not long time ago, other country claimed that batik was the original culture of its own country. Now that the situation has subsided, the country no more continues to claim batik. In this case, the united nations represented by UNESCO made official statement as described above (Ricklefs, 2005).

Batik was officially recognized as one of Indonesia's cultural heritage by UNESCO on October 2, 2009. The word batik comes from the word "ba" and "tik", which means "the dots". Furthermore, UNESCO's recognition also had positive impact on batik sales, especially in terms of promotion, from having a role as a cultural heritage, batik also has an economic function (Sari et al., 2020).

Batik in the Java concept contains more tangible spirit, which is a philosophical symbol closely related to the meaning. The name of batik comes from the combination of the two meaningful words "amba" in Javanese means writing and of "tik" means point. Central Java batik is characterized by its motives derived from Javanese culture. It is closely related to Hindu culture, Islamic culture and Chinese, Dutch, Arab, Indian, Japanese and other mixtures with philosophical and artistic values. The development of batik has become more

\footnotetext{
${ }^{1}$ Firman Bachtiar, dr, MM, Lecturer, Politeknik Saw Unggalih Aji, Purworejo, Indonesia, e-mail:
} firmandian63@gmail.com, ORCID: 0000-0001-7646-9807. 
and more extensive and become one of professional knowledge that can be continuously developed. Batik is also cultural heritage of society and should be maintained and preserved to ensure the environmental safety from chemical pollution. It indicates that the basic theoretical research methods based on constructivism have expanded the complexity of social life. (Hastuti and Sihombing, 2020).

Batik patterns divided into multiple design groups are related to the certain qualifications and variations. Batik patterns have similarities, thus, it can be recognized. The patterns developed based on high-level features that did not change proportions, rotations, and other. Batik is a traditional cloth with unique patterns that can be applied to fabrics. Wax resistant coloring technology (Mulyani et al., 2019).

An approach to batik pattern recognition using Scale-invariant feature transform (SIFT) as a feature of extraction method. Batik can be divided into several types: written (handmade), printed, and fabric pattern without any process. Hand-made batik tends to be considered having higher quality and demand by most of people and art lovers, however the manufacturing process takes a long time, starting from the process of making pattern, writing (handmade) using specialized equipment tjanting, coloring, removing, and washing. The longest process is hand-drawing which can take up to weeks or months depends on the complexity of patterns (Mulyani et al., 2019).

It makes the price of hand-made batik expensive, and even only a piece of cloth can reach millions of rupees. In the optimization of batik, the use of particle swarm optimization (PSO) method help to save $14.801 \%$ of raw materials and $10.345 \%$ of production time. This method was introduced to speed up the production process and reduce the price of batik (Mulyani et al., 2019).

The world recognition of batik had an impact on the spread of batik to the world. According to the Ministry of Industry, the value of batik exports in 2015 reached US 156 million. However, batik exports tend to experience a downward trend until 2019. In 2018, batik exports reached US 52.44 million. This value has decreased by $10.3 \%$ compared to the previous year. The exports of batik in first semester of 2019 obtained to US 17.9 million. The most significant decline occurred in 2017, where the value of decline reached $61 \%$ compared to the previous year. The main export destinations of batik include Japan, United States and Europe (Sari et al., 2020).

The development of batik has grown along with the development of kingdoms era in Indonesia, especially in Java, and dissemination of Islam in XVII Century. Nowadays, batik's culture had spread all over not only in Java, but had reached many areas outside Java Island. A number of cities and areas which were familiarized and has an impact on the development batik such as Surabaya, Gresik, Madura, Solo, Yogya, Banyumas, Cirebon, Padang, Kalimantan, Sumatra (Longenecker, Moore and Petty, 1994).

After several centuries, the growth and development of batik cultures had spread all over Nusantara. It could be mentioned that, the name of batik were connected to the city and region where the batik were made such as, Pekalongan batik, Banyumas batik, Yogyakarta batik, Solo batik, Surabaya batik, Cirebon batik, Jambi batik, Kalimantan batik, and Papua batik. Each and every kind of Indonesian Batik has their own patterns that normally represent the region's characteristics and history (Ricklefs, 2005). Every patterns hold particular meanings of respective regions. It is appropriate that batik becomes one of Indonesia's culture, which is very valuable and worth to preserve by every Indonesian people (Cooper and Schindler, 2000). 
Batik Purworejo was famous several years ago due to the unique pattern. However, the development period related to the technology, global competitiveness and communication, taste, a number of cities and region which in the past already had batik culture, and it slowed but sure began to fade (Goldstein, 2007).

Then the research focus was directed to the profile of businessman and batik craftsmen that were spread out over Purworejo. The day-to-day activities they perform in course of conducting business, and the stage of competence in conducting business. They may get the opportunity to grow their business (Levy, Weitz and Grewal, 2001). The restrictions they may face in running a business. They expect government agents to supervise to improve competitiveness. In this study, the purpose is to provide the Purworejo batik process and local governments with opinions on the obstacles and recommendations regarding the sustainability of Purworejo batik. (Nitisusastro, 2010).

\section{METHODOLOGY}

To find a supervising and developing alternative solution for small and middle scale enterprises and boost the competitive advantage, it had to be found some main elements that fits to the point on statement of problem, research objective, the use of research, qualitative methods was applied in this research (Denzin and Lincoln, 2009).

In this research the things that will be observed were people, those who acted as an actor in the small and middle scale enterprises with their various back ground (Sugiyono, 2016). The players in small and medium scale enterprises run their activity, which were in this case in Purworejo Region. Interaction between business players (actors), their activities (Sigit, 2003), and locations (place) will result such certain situation. As mentioned above, the research sample will be several small and medium scale of enterprises that active in field of batik business.

Data and interview also conducting in Rural Development Planning Board (Badan Perencanaan Pembangunan Daerah), small and medium scale enterprises, and cooperative Office (Moleong, 2017). The research was done for more than three months to study people as the object of observation, they are the subject of small and medium-sized enterprises within the various backgrounds (Sugiyono, 2009). There are five samples of small to medium participated enterprise. Three samples from small batik business and the other two are from medium level batik business. It includes the interaction between business participants (actors), their activities (events) and locations (places) which made such situation. Data and interviews were also conducted in Rural Development Planning Committee (Badan Perencanaan Pembangunan Daerah), SMEs and Cooperative Office (Moleong, 2017).

\section{RESULTS}

Nowadays in Purworejo, only handmade or handwritten batik exists. There is no more printed batik produced and it was a decrease condition since the majority of customer can afford to purchase printed batik for economical consideration. In the past ten years, the amount of business unit of batik craft in Purworejo has been decreased. There is no systematical regeneration planning and new generation has less interest in batik crafting, moreover there is no intention to attract younger generation. The amount of batik craft is reduced because there is no more successor (Griffin and Ebert, 2004). 
The observation indicated several weakness as the problem that needs new strategy to be formulated. The detail of problem can be seen in the table below:

Table 1. Batik Business Problem Categories

\begin{tabular}{|c|l|c|c|c|c|}
\hline \multirow{2}{*}{ No } & \multirow{2}{*}{ Category } & \multicolumn{4}{|c|}{ Problems } \\
\cline { 3 - 6 } & & Promotion & Buyers & Logistic & Innovation \\
\hline 1 & Sample 1 & $\checkmark$ & & $\checkmark$ & \\
\hline 2 & Sample 2 & $\checkmark$ & & $\checkmark$ & $\checkmark$ \\
\hline 3 & Sample 3 & & $\checkmark$ & & \\
\hline 4 & Sample 4 & & $\checkmark$ & & $\checkmark$ \\
\hline 5 & Sample 5 & $\checkmark$ & $\checkmark$ & & \\
\hline
\end{tabular}

Source : Survey Data.

Based on the table above, most of problems happen on the factor of promotion which cause the decrease on the number of buyer. Furthermore, lack of innovation of Batik has also become an important factor to attract buyers from every kind of class and age.

Therefore, several recommendations of strategies that can be used by batik craftsmen, it was done based on the results of value chain analysis, which includes upstream, midstream, and downstream segments. Business clusters are industrial zones where businesses, various public and private sector industries that were operated by their suppliers and other connections. Therefore, prioritized innovations in inbound logistics, operation, and marketing and sales area, success is not achieved in industries which could not realize their external integration, but in business clusters. Porter in Sari pointed out that it is expected that the craftsmen can increase the productivity of their businesses, thus it will able to compete in the current market. Developing the clusters will increase the speed of obtaining competitive benefit. In the batik industry, every elements that have advantages as an effort to increase the competitive benefit (Sari et al., 2020).

The strong promotion is still required. For batik home industry, the owners that continue to develop batik should always improve the quality of batik production, and develop the shades which are taken from local culture, Indonesian or foreign people should be proud to wear batik as the culture of region. Local government is necessary to support the program and promote batik that contains the values of culture and develop batik as a master of its own areas (Hengky, 2018).

\section{DISCUSSION}

Sudantoko in Suryani pointed out that the value of national batik industry production in 2010 reached USD 8,4 billion which employ 17.082 people in 326 business units in Indonesia. It stated that Batik has become part of creative industries and business sector has comparatively and competitively able to exploit natural resources or potential areas in Indonesia (Suryani, Anggraeni and Suryadi, 2015).

There are also a number of constraints from the raise of rough material prices, difficulties for the future generation, limited capital and less strategic of production place. In demanded conditions construct, it explains that the high number of buyers and the type of pattern can be supporting factor of business. The availability of rough materials from the 
outside of the city can be an industrial obstacle. Furthermore, the existence of stronger market competitor and the existence of batik printing can prevent further income of batik, thus, there are unable to manage the business properly (Sari et al., 2020).

The role of small industry in Indonesia is associated with the government's efforts to reduce the number of unemployment, poverty and raise the distribution of income. The potential prospects of small industries to strengthen the productive capacity of small industries within the higher amount of unit. Small industries which have a strong network will have more important role on its development than those with a weaker network. The ability of small industries would promote the establishment of strong partnership which is conducive for larger corporations and small business (Pudjowati et al., 2019).

The benefit of beng competitive describes an innovation role on creating the company's competitiveness. It is important innovation strategy to increase the competitive benefit as dependent variable, the research results explain positive effect. The innovation activity is a product report card with Enhanced quality enhancement, superior quality service, novel, more efficient, and cleaner production (Za et al., 2019).

One of the important tool in tourism development is the future orientation. In the involvement stage, it focuses on distributing economic benefits and protecting natural resources by providing education to the community, able to provide facilities and amenities, offer local wisdom as a tourist attraction to generate employment and income opportunities. Tourism should also consider the aspects of sustainability, socially, economically and in natural resources and borrowing the term of "sustainable development" (Lubis, Rohmatillah and Rahmatina, 2020).

Hastuti and Sihombing, (2020) stated that the awareness of cultural development of batik by entrepreneurs can be examined based on the three types. Cultural development that was taken by entrepreneurs can be traced within the three aspect: (1) maintain and develop business community (2) keep the relic style and the color of batik (3) keep the family business stable. Meanwhile based on this research, the cultural development begin to decrease in modern era. Thus, this research tried to build alternative strategies to maintain the cultural development of Batik business.

Widiana et al., (2020) stated that the design of gallery or showroom and employees uniform and attributes have been well prepared, a prototype cashier application and dashboard for management have been tested and well implemented. It will certainly runs the activities of mentoring, monitoring and evaluating the implementation that was carried out by partners. The solution provided for partners to compete at national and international level is conveyed through several activities such as preparing to build a gallery or exhibition hall, preparing employee attributes and cashier applications. every solutions that have been offered have a purpose to build the market and increase the sales which have an impact on increasing the partners income.

Textile industry is currently in the 3rd position of national exports and engaging the employment for more than 2.79 million people by obtaining production which is able to meet 70 percent of domestic clothing needs. Furthermore, throughout 2015, the textile sector has contributed 1.22 percent to the National GDP and an export surplus of USD 4.31 billion (Suparno et al., 2019).

Batik crafting is now spread out in 2 sub-region and 6 villages which include Kemanukan, Rejosari, Bakurejo, Dudukulon, Duduwetan and Sumber Agung. The total of business units are 154 , producing 1.848 pieces every month. 
Batik is an art, or written art upon a piece of fabric that was made from unbleached plain cloth, by using drawing tool called "canting" and ink that made from resin torch or candles. The pattern is designed from the inspiration of designers or craftsmen, based on their imagination on flora, fauna and their surrounding environmental condition (Sudja, 1979).

Nowadays, the stages of competences have become less or even lost because there is no successor from the younger generation or family, even though normally the crafting ability is passed down for the generations below (Sudja, 1979). "Batik tulis", or written batik consist as a unique art because of the high category. It also takes more time and effort to make, thus the price is relatively more expensive and less people can afford this type of batik (Sudja, 1979).

The materials for batik such as kain mori, blacu, lilin, malam, and pewarna have become difficult to find in Purworejo and it requires a bit more effort to purchase in Yogyakarta. Despite, the fact that batik can be done practically on any media, it is not limited to kain blacu, the skill and knowledge of this are yet to be distributed to the craftsmen and entrepreneurs in Purworejo. Even some Indonesian designers have started to apply batik on silk and leather on bags. It proves that there is information and knowledge gap (Sudja, 1979).

The existence of Balai Batik under the Ministry of Industry that located in Yogyakarta doesn't seem to give any solution to this issue at the moment. The place and association haven't been optimally utilized by the surrounding society. The choice of materials, colors, equipment, the process and maintenance of batik colors still using the conventional methods, despite being the ones that have been passed on through generations, it is also limited (Nitisusastro, 2010).

The human resources of batik is mostly woman and it is not a primary job, which is mainly farming, and the skill to create batik was passed down from mother to daughter. Since it takes a long time to make batik, it has become a secondary job besides farming. Which is to craft batik, it takes time and particular skills that should not be dismissed as a side work (Siropolis, 1994).

Even in Purworejo, it does not familiar that there is Batik with a unique pattern which originally from Purworejo. It has close relation with the vernaculars, social capacity, and the local customs that have been lost in general society. Nowadays, it can be seen that no one needs to wear original Batik because they will be considered as traditional people by society. Besides, teenagers nowadays is about lifestyle (Day, 1999).

The infrastructure such as electricity is often need more support for batik crafting, hence, the instability of lighting to maintain the process of making batik during the night need more precision. Aside from the use of traditional lightning, it also needs improvement. If the deficiency during the process being listed, it would take long list. It seems that every process to made Batik is not following the improvement of technology (Alma, 2010).

\section{CONCLUSION AND RECOMMENDATION}

Although batik Purworejo had been famous now, there are several issue regarding this problem that need a solution.

Since mostly Batik industries are run by small enterprise, the support is needed from the local government because, batik Purworejo has their unique pattern that can be considered as local heritage according to the UNESCO. UNESCO declared that Batik was as a human Non Physical heritage from Indonesia. The support is also required from the people of 
Purworejo, they should be proud and love to wear and participate in preserving their wealth of Batik Purworejo. Let the future generation know that it is okay to learn and wear foreign fashion. However, it needs to guide and guard them at the same time and should not ignore the heritage, did not let them become apatism for national heritage.

Based on the educational point of view, local government should obtain the activities outside the academics which are known as the extracurricular activities in the early stage of school as elementary school. The students should be familiar with Batik, the process of making, and designing it. For senior or higher education level, they can start to like Batik compete in fashion show with other school or invite school from other regency to implement the program. However, they should adequate knowledge first. The information regarding Batik should be a part of the program. Building their self-esteem through the cultures and made them love it.

For the batik industries which include as small enterprise need more improvement for the physical equipment to maintain the sustainability of production, training for successor or younger generation since new generation mostly choose another job sector, improvement on the logistic regarding the production material of batik crafting can save time also obtain a better price.

Local government also needs to realized that batik Purworejo is a heritage that needs support and attention by relevant trainings, support for basic infrastructure such as electricity and access for funding. Associated with the Balai Batik under the Ministry of Industry and utilizing it to its maximum potential, upgrade the knowledge and skill and the function of technology to empower the craftsmen and entrepreneurs of Batik Purworejo, by organizing the batik trainings in 154 Batik centrals.

The information and the right market, by collaboratingwith the trading agency and also local governments, they can propose and send the competent and approved Batik entrepreneurs to join exhibitions within the country and even internationally. Local government can make a suggestion for the entire employee to wear Batik in a specific day, not just ordinary Batik but especially for Batik Purworejo. The government should be responsive in dealing with this issues by oversee our own culture heritage.

$$
* * * * * *
$$

\section{ACKNOWLEDGMENT}

We would like to thank to the Bupati, Wakil Bupati Purworejo, Bappeda, Diskoperindag for welcoming and time consuming during visiting and interview also the most important to batik Purworejo crafts SMEs to share the knowledge and information for the better future of sustainability batik Purworejo and our willingness to preserve, maintain and posibility to develop our heritage.

\section{REFERENCES}

Alma, B. (2010). Kewirausahaan. Bandung: Alfabeta.

Cooper, D. R., Schindler, P. S. (2000). Business Research Methods. 7th (Seven). Toronto: McGraw-Hill.

Day, G. S. (1999). Market Driven Strategy: Processes for Creating Value. New York: Free Press.

Denzin, N. K. and Lincoln, Y. S. (2009). Handbook of Qualitative Research. Yogyakarta: Pustaka Pelajar. 
Goldstein, B. (2007). The Ultimate Small Business Marketing Toolkit: All the Tips, Forms, and Strategies You'll Ever Need. 1st editio. Toronto: McGraw-Hill.

Griffin, R. W., Ebert, R. J. (2004). Business. Seventh Ed. New Jersey: Prentice-Hall, Pearson Education International.

Hastuti, T. D. and Sihombing, R. P. (2020). Analysis of Entrepreneurial Development of Natural Coloring Batik: A Case Study in Central Java Indonesia. "Journal of Business and Finance in Emerging Market", 2(2).

Hengky, S. (2018). Batik-Craft Tourism's Competitiveness in Madura, Indonesia. "Journal of Management Research", 10(4). DOI: 10.5296/jmr.v10i4.13623.

Levy, M., Weitz, B. A. and Grewal, D. (2001). Retailing Management. Internatio. Toronto: McGrawHill Irwin.

Longenecker, J. G., Moore, C. W. and Petty, J. W. (1994). Small Business Management: An Entrepreneurial Emphasis. 12th editi. Ohio: South-Western College Pub.

Lubis, H., Rohmatillah, N., Rahmatina, D. (2020). Strategy of Tourism Village Development based on Local Wisdom. "Jurnal Ilmu Sosial dan Humaniora". DOI: 10.23887/jishundiksha.v9i2.22385.

Moleong, L. J. (2017). Metodologi Penelitian Kualitatif (Edisi Revisi) [in:] PT. Remaja Rosda Karya.

Mulyani, N. S. et al. (2019). Implementation of Cultural Heritage in the Development of the Batik Industry in Ngawi Regency. "Universitas Sebelas Maret Repository".

Nitisusastro, M. (2010) Kewirausahaan \& Manajemen Usaha Kecil. Bandung: Alfabeta.

Pudjowati, J. et al. (2019). The Influence of Business Network and SME Empowerment Towards Business Sustainability (Study of Handmade Mangrove Batik SME Surabaya). "Journal of Engineering and Applied Sciences". DOI: 10.36478/jeasci.2019.6625.6633.

Ricklefs, M. C. (2005). Sejarah Indonesia Modern 1200-2004. Jakarta: Serambi Ilmu Semesta.

Sari, S. R. et al. (2020). Value Chain Analysis on Handmade Batik Products. JEJAK. DOI: 10.15294/jejak.v13i1.21771.

Sigit, S. (2003). Pengantar Metodologi Penelitian Sosial-Bisnis Manajemen. Cetakan Ke. Yogyakarta: Penerbit Bagian Penerbitan Fakultas Ekonomi Universitas Sarjanawiyata Tamansiswa.

Siropolis, N. C. (1994). Small Business Management: A Guide to Entrepreneurship. 5th editio. Boston: Houghton Mifflin Co.

Sudja, W. A. (1979). Proses Pembuatan dan Pewarnaan Batik di Indonesia. Bandung: PT Karya Nusantara.

Sugiyono (2009). Metode Penelitian Kuantitatif, Kualitatif dan R\&D. Bandung: Alfabeta.

Sugiyono (2016). Memahami Penelitian Kualitatif. Bandung: Alfabeta.

Suparno, S. et al. (2019). The Determinant Factors of Development Batik Cluster Business: Lesson From Pekalongan, Indonesia. "The Journal of Asian Finance, Economics and Business, 6(4). DOI: 10.13106/jafeb.2019.vol6.no4.227.

Suryani, I. E., Anggraeni, L. and Suryadi, U. (2015). Strategy Formulation for Developing Batik Tulis. "Indonesian Journal of Business and Entrepreneurship", 1(1). DOI: 10.17358/IJBE.1.1.23.

Widiana, M. E. et al. (2020). The Improving of the Quality Resources of Gedog Batik Craftsmen in Tuban Regency. "Indonesian Journal of Cultural and Community Development", 7. DOI: $10.21070 / \mathrm{ijccd} 2020683$. 
Za, R. et al. (2019). Innovation and Marketing Strategy for Batik Products In The Industrial Age 4.0. "International Journal of Recent Technology and Engineering", 8(2S9). DOI 10.35940/ijrte.B1116.0982S919.

DOI: 10.7862/rz.2021.mmr.08

The text was submitted to the editorial office: May 2021.

The text was accepted for publication: June 2021. 
